\title{
Determinants of Inward Foreign Direct Investment: A Dynamic Panel Study
}

\author{
Stephen G. Grubaugh ${ }^{1}$ \\ ${ }^{1}$ Department of Economics, Bentley University, USA \\ Correspondence: Stephen G. Grubaugh, Department of Economics, Bentley University, 175 Forest Street, \\ Waltham, MA 02474, USA. Tel: 1-781-891-2539. E-mail: sgrubaugh@bentley.edu
}

\author{
Received: July 24, $2013 \quad$ Accepted: October 21, $2013 \quad$ Online Published: November 26, 2013 \\ doi:10.5539/ijef.v5n12p104 URL: http://dx.doi.org/10.5539/ijef.v5n12p104
}

\begin{abstract}
Most recent studies of the factors that determine flows of foreign direct investment have focused on bilateral flows of FDI using a wide array of possible variables. Recent studies of the aggregate flows of FDI (flows from all sources) have been limited in the type and number of countries included. This study adds to these results by using a panel data set that includes 74 countries for the period 1980-2008 over a wide-range of countries. An important result of this study is that the relationship between FDI and measures of market size and income is non-linear. To study the effects of country specific characteristics this study looks at the relationship between the average country residual from the panel estimates and various measures of business climate.
\end{abstract}

Keywords: Foreign Direct Investment (FDI), dynamic panel estimation, business climate

\section{Introduction}

Foreign Direct Investment (FDI) has continued to be an ever increasing aspect of the world economy. For example, FDI as a percent of world GDP averaged $0.66 \%$ per year in the $1980 \mathrm{~s}, 1.43 \%$ per year in the $1990 \mathrm{~s}$ and $2.97 \%$ per year in the 2000s (World Bank, World Development Indicators). It is not surprising, then, that there have been a large number of studies that have attempted to model the determinants of the flows of FDI. Any insight into these flows will help us better understand the global economy. Many countries have policies in place to attract FDI. Without a firm understanding of what exactly does attract FDI and what does not, these policies may be at best wasteful or even counter-productive. With that goal in mind, this study looks at the aggregate flow of inward FDI in a broad range of countries. Specifically this study differs from previous analyzes by looking at (1) a large number of countries (74) at all levels of economic development; (2) a panel data set incorporating 20 years of data for each of the countries (1980-2008); (3) aggregate inward flows of FDI rather than focusing on bilateral flows; and (3) using a residual analysis similar to the Solow residual approach for measuring technological change as a way to measure the effect of country policies on attractiveness for inward FDI.

\section{Previous Studies}

A recent review of the literature by Blonigen (2005) concluded that "our theoretical hypotheses come out of modeling firm-level decisions. "Building on models of firm behavior, these empirical investigations have generally been cross-country studies of bilateral flows of FDI. These studies then look at how macroeconomic factors may influence a firm's decision concerning FDI. The results from such studies have been widely varying. Several recent attempts have been made to reconcile these widely varying results by using various modeling selection theories (Chakrabarti, 2001; Blonigen \& Piger, 2005; Eicher, Helman, \& Lenkoski, 2012).

A major problem with this theoretical approach is that many countries end up excluded from the sample because the information on bilateral flows is simply not available in sufficient detail. One approach to this problem is to see this as a possible sample selection bias (Eicher et al., 2012). This paper, instead, does not use bilateral flows but aggregate flows. Our emphasis from the beginning is the macroeconomic factors that influence the FDI decision.

Several recent studies have looked at aggregate flows using a panel data set. Recent examples include Aseidu (2002) that studied a sample of 71 developing countries for the period 1988-97; Mohamed and Sidiropoulos (2010) that studied 36 developing countries for the period 1975-2006; Fukumi and Nishijima (2010) that studied 
19 countries in Latin America and the Caribbean for six 3 year sub-periods from 1983 to 2000; and Krifa-Schneider and Matei (2010) that studied 33 developing countries for the period 1996-2008. Of these studies, only Kirfa-Schneider and Matei (2010) used the Arellano and Bond (1991) dynamic panel model that has been found to be more appropriate for panels such as these with several countries over only a few years (see Holtz-Eakin, Newey, \& Rosen, 1988) rather than the fixed-effects model used in the other studies.

This paper differs from these recent studies in several respects. First, this study is not limited to developing countries. The countries used in this study include very low-income developing countries, middle-income countries, and high-income countries. Second, the approach in this study is to develop a model of macroeconomic variables that attempt to measure the attractiveness of countries for inward FDI. Using an approach similar to the Solow growth model, the residuals of this model are then used as a measure of the extent specific policies of countries with regard to business formation and taxation are related to the flow of FDI being either above or below what would be expected from the purely macroeconomic characteristics of the country. Third, the dependent variable in this study will be the total aggregate flows of inward FDI measured in constant PPP adjusted US dollars. All of the previous studies have used FDI as a percent of current GDP. This study will instead use GDP (in a non-linear form) as one of the macroeconomic variables determining the flow of FDI rather than impose the (implied) functional form that FDI and GDP have a one-to-one linear relationship.

\section{Data and Methodology}

All the data used in this study are from the World Bank, World Development Indicators. There are 74 countries in the sample (see Table 2 for a list) for the years 1980-2008. The dependent variable is inward FDI measured in constant PPP adjusted US dollars. The macroeconomic variables of interest (all in PPP adjusted US dollars) are (1) GDP as a measure of market size; (2) per capita GDP as a measure of wealth and a proxy for wages; (3) growth rate of real GDP as a measure of the strength of the economy and the effectiveness of macroeconomic policies; (4) exports plus imports as a percent of GDP as a measure of the openness of the country; (5) total bank credit as a percent of GDP as a measure of the financial development of the country; (6) number of telephone lines per 100 people as a measure of the development of infrastructure in the economy; and (7) Natural resource rents as a percent of GDP as a measure of the importance of natural resources in the economy. Using the Arellano and Bond model the estimation also includes lagged values of the dependent variable. First differences of all of the independent variables are used as instruments to adjust for any simultaneity issues. To allow for non-linearity, the square of both real GDP and per capita real GDP are also used as independent variables.

The second step in the analysis is to take the residuals of this macroeconomic model as a measure of whether the country has attracted FDI at a rate greater or less than an average country with the same characteristics. Using the average value of the residual for the entire time period (1980-2008) as the dependent variable, a model is estimated to attempt to relate the attractiveness of the country for inward FDI to measures of economic policy. The variables used to measure policy are all indexes developed by the World Band (World Development Indicators). The World Bank has only recently begun to measure these values and they have generally changed very little over this brief period so the values for 2009 were used. These measures are: (1) Disclosure Index (1-10), a measure of the extent to which investors are protected through disclosure of ownership and firm information; (2) Start-up cost (percent of GDP); (3) Depth of Information Index (1-6), the extent of rules effecting scope, accessibility and quality of credit information available; (4) Legal rights index (0-10); (5) Labor tax (percent of profit); (6) Profits tax (percent of profits); and (7) Other taxes (percent of profits). The World Bank uses these seven indicators to rank countries from best to worst for what it calls "Ease of Doing Business". 
Table 1. Coefficient estimates

\begin{tabular}{lll}
\hline Independent Variable & Coefficient & z-statistic \\
\hline Real GDP & 0.0096 & 118.26 \\
Real GDP squared & $6.97 \times 10^{-17}$ & 15.67 \\
Real GDP per capita & $-2.28 \times 10^{6}$ & -131.86 \\
Real GDP per capita squared & 48.76 & 160.76 \\
Growth (\% change real GDP) & $1.61 \times 10^{8}$ & 127.30 \\
Openness (Exports+Imports/GDP) & $6.02 \times 10^{7}$ & 164.00 \\
Bank Credit & $-3.54 \times 10^{6}$ & -10.92 \\
Telephone lines per 100 & $4.11 \times 10^{8}$ & 491.65 \\
Natural Resource Rents (\%GDP) & $3.41 \times 10^{7}$ & 20.66 \\
Lagged FDI & 0.5144 & 18400 \\
Wad test for overall fit & $\chi^{2}(9)=2.74 \times 10^{6}$ & $\mathrm{p}$-value $=0.000$ \\
Test for autocorrelation & $\mathrm{z}=0.099$ & $\mathrm{p}$-value $=0.922$ \\
Sargan test & $\chi^{2}(377)=80.61$ & $\mathrm{p}$-value $=0.999$ \\
\hline
\end{tabular}

Table 1 shows the Arrellano-Bond Dynamic Panel estimates (GMM) of the model with FDI as the dependent variable. The z-statistic is based on robust standard error estimates.

\section{Empirical Results}

The results from the GMM estimation of the equation relating inward FDI to the seven macroeconomic variables (plus 2 second order terms) are reported in Table 1. Overall the estimation meets the basic criteria for a useful estimation. First, the model passes the Sargan test of the over-identifying restrictions implied by the use of the instrumental variables since the test statistic $\left(\chi^{2}(377)=80.612\right)$ would not reject the null hypothesis that the over-identifying restrictions are valid at any significance level. Second, the test-suggested by Arellano and Bond for autocorrelation in the presence of first-differenced errors cannot reject the hypothesis of no autocorrelation $(\mathrm{z}=0.098)$ at any significance level. Finally, all of the variables are significant at a significance level of at least 0.01 .

The results for using real GDP as an independent variable using a second-order non-linear model are of particular note. Data for inward FDI are generally reported as a percent of GDP. Previous studies have generally used this percentage measure of inward flows of FDI as the dependent variable in models of the determinants of FDI flows. The results, here, though indicate that this is a misspecification and that the relationship between FDI flows and the size of the market is non-linear. Specifically, these results show a positive relationship between size and FDI flows with the relationship growing at an increasing rate.

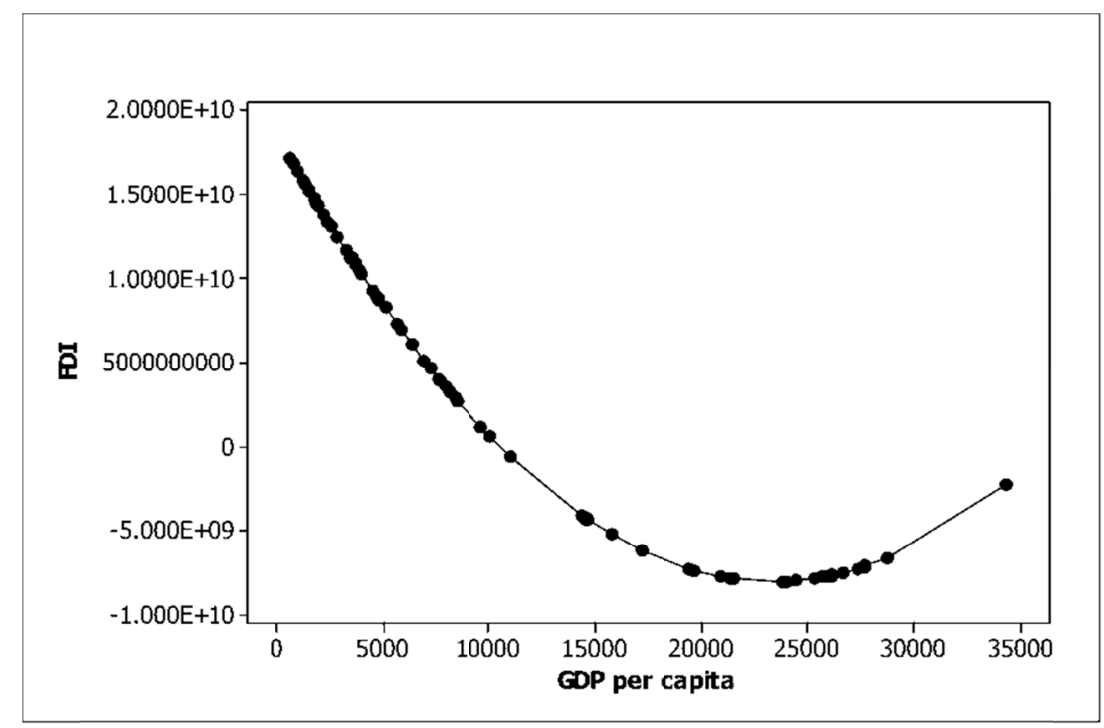

Figure 1. Scatterpolot of FDI and GDP per capita 
This graph shows the estimated relationship between GDP per capita and the flows of FDI. All other variables are measured at their overall mean.

The results for real per capita GDP are also interesting. This variable is a proxy for two (conflicting) reasons for a firm to choose a country as a possible location for FDI. If the firm is looking for a location where production of a good would be at a low-cost, then a country with low wages would be preferable. While not perfect, per capita GDP is clearly a reasonable proxy for the level of wages. On the other hand, if a company is looking for a location to produce a good or service where there is a large demand for the product, real per capita GDP is a good proxy for higher-income countries where the demand for goods and services would be higher.

Figure 1 shows the relationship between real per capita GDP and FDI. Using the mean values of all other variables for the entire sample, the graph plots the relationship from the estimates. The estimates imply that real per capita GDP and FDI have a negative relationship until a real per capita GDP reaches a value of $\$ 23,394$. After this level of income is reached, there is a positive relationship between real per capital GDP and FDI. The search for low wages and the country as a platform for exports would seem to dominate the choice of location by firms (holding the effect of natural resources constant) up to the development level of about Ireland (average real per capita GDP over the period of $\$ 23,873$ ). After that level of development, the attraction of a larger market for goods sold in the country dominates the choice of firms.

All of the other results from the panel estimation shown in Table 1 are statistically significant at any level and consistent with expectations. Inward flows of FDI are positively related to economic growth, the level of openness of the economy, the level of infrastructure development (telephone lines per 100), and the importance of natural resources in the economy. Inward FDI is negatively associated with the level of (domestic) bank credit (a substitute for direct foreign investment).

The fitted values of this estimated equation can be viewed as the expected value of inward FDI for an economy in each particular year. The difference between these predicted values and the actual inward FDI (the residuals) can, therefore, be interpreted as showing the extent to which the country's policies make this location more or less attractive, holding constant the macroeconomic position of the country. In Table 2 we use the mean residual to rank each country's attractiveness for FDI. Countries are listed in order from those with the most negative mean residual to the highest positive residual. The countries are divided into three groups based on

Table 2. Countries by mean residual

\begin{tabular}{lll}
\hline Mean Residual negative & Residual mean zero & Mean Residual positive \\
\hline United States & Syrian Arab Republic & Bolivia \\
Japan & Malaysia & Paraguay \\
India & France & Costa Rica \\
Lesotho & Ireland & Finland \\
Indonesia & Nicaragua & Turkey \\
Papua New Guinea & Sudan & Brazil \\
Swaziland & Thailand & Dominican Republic \\
St. Vincent and the Grenadines & Mauritius & El Salvador \\
Malawi & Egypt, Arab. Rep. & Guatemala \\
Korea, Republic & Panama & Austria \\
Fiji & Netherlands & Greece \\
Jordan & Tunisia & Australia \\
St. Kitts and Nevis & & Ecuador \\
Italy & & Colombia \\
Congo, Republic & & Uruguay \\
Ghana & & New Zealand \\
Denmark & & Israel \\
Canada & & South Africa \\
St. Lucia & & Seychelles \\
Sweden & & Botswana \\
Sierra Leone & & Peru \\
Philippines & Chile \\
Senegal & & Portugal \\
Kenya & & Spain \\
\hline
\end{tabular}




\begin{tabular}{ll}
\hline Madagascar & Mexico \\
Honduras & Trinidad and Tobago \\
Sri Lanka & Venezuela \\
Central African Republic & United Kingdom \\
Iceland & Belgium \\
Pakistan & Saudi Arabia \\
Cote d'Ivoire & Gabon \\
\hline
\end{tabular}

whether the mean residual is significantly below zero, above zero, or statistically insignificantly different from zero.

Table 3 reports the results of trying to understand what, if any, policy differences among these countries might explain this relative difference in countries (average) attractiveness as a location for FDI. Using the ranking of countries from most negative (US) to most positive (Gabon) as the dependent variable, this regression uses the seven measures that the World Bank has generated to rank countries for their ease of doing business. Of the seven measures only the depth of information index is significant at the $5 \%$ level. In addition, start-up costs (as a percent of GDP) and Other taxes (as percent of profits) are significant at the $10 \%$ level.

Table 3. Coefficient estimates

\begin{tabular}{lccc}
\hline Independent Variable & Coefficient & z-statistic & p-value \\
\hline Disclosure Index & -0.0777 & -0.63 & 0.534 \\
Start-up costs & -0.2528 & -1.88 & 0.065 \\
Depth of Information index & 0.2737 & 2.35 & 0.022 \\
Legal rights index & -0.1542 & -1.12 & 0.268 \\
Labor tax & 0.1020 & 0.79 & 0.431 \\
Profits tax & -0.1353 & -1.10 & 0.274 \\
Other taxes & -0.2085 & -1.87 & 0.066 \\
Constant & 54.4776 & 3.60 & 0.001 \\
R2 & 0.252 & & \\
adj. $\mathrm{R}^{2}$ & 0.172 & & \\
Overall significance test & $\mathrm{F}(7,66)$ & 3.17 & 0.006 \\
Test for heteroscedasticity & $\chi^{2}(1)$ & 0.18 & 0.676 \\
\hline
\end{tabular}

Table 3 shows the OLS estimates of the model with mean residual (negative to positive) as the dependent variable.

\section{Conclusions}

This study adds to the current literature by using a panel of countries that include the entire range of economic development rather than simply focus on a select group of developing countries. This is possible, partly, because of the use of aggregate inward FDI as the variable of interest rather than bilateral flows of FDI, which places great restrictions on the countries that can be included in the study. In addition, this study used as a measure of FDI the amount of FDI rather than the more traditional FDI as a percent of GDP. The results from the estimation showing a non-linear relation between these flows of FDI and GDP imply that the traditional form is a mis-specification. In addition, allowing real per capita GDP to have a non-linear (second-order) relationship to inward flows of FDI better captures the dual role of per capita GDP as both a proxy for wages and for consumer income.

The results from using the (mean) residuals for each country as a measure of policy choices that make a country more or less attractive for inward FDI was less successful. The measures used for policy choices were taken from the World Bank, World Development Indicators, and have only a short history. This required that we use the average for each country rather than look at each country over time. In addition, these measures of attractiveness for business are mostly rough indexes generated by the World Bank or overall indicators (such as tax payments) that may miss many nuances that would be of importance to multinational firms as they decide where to invest. As these variables accumulate over time and (hopefully) improve, future research may be better able to determine which policies best explain the relative attractiveness of countries for FDI. 


\section{References}

Arellano, M., \& Bond, S. (1991). Some tests of specification for panel data: Monte Carlo evidence and an application to employment equations. Review of Economic Studies, 58(2), 277-297. http://dx.doi.org/10.2307/2297968

Asiedu, E. (2002). On the determinants of foreign direct investment to developing countries: Is Africa different? World Development, 30(1), 107-119. http://dx.doi.org/10.1016/S0305-750X(01)00100-0

Blonigen, B. (2005). A review of the empirical literature on FDI determinants. Atlantic Economic Journal, 33(4), 383-403. http://dx.doi.org/10.1007/s11293-005-2868-9

Blonigen, B., \& Piger, J. (2011). Determinants of foreign direct investment. National Bureau of Economic Research Working Paper 16704.

Chakrabarti, A. (2001). The determinants of foreign direct investment: Sensitivity analyses of cross-country regressions. Kyklos, 54(1), 89-114. http://dx.doi.org/10.1111/1467-6435.00142.

Eicher, T., Helfman, L., \& Lenkoski, A. (2012). Robust FDI determinants: Bayesian model averaging in the presence of selection bias. Journal of Macroeconomics, 34(3) 637-651. http://dx.doi.org/10.1016/j.jmacro.2012.01.010

Fukumi, A., \& Nishijima, S. (2010). Institutional quality and foreign direct investment in Latin America and the Caribbean. Applied Economics, 42(14), 1857-1864. http://dx.doi.org/10.1080/00036840701748979.

Holtz-Eakin, D., Newey, W., \& Rosen, H. (1988). Estimating vector autoregressions with panel data. Econometrica, 56(6), 1371-1395. http://dx.doi.org/10.2307/1913103.

Kirfa-Schneider, H., \& Matei, I. (2010). Business climate, political risk and FDI in developing countries: Evidence from panel data. International Journal of Economics and Finance, 2(5), 54-65.

Mohamed, S., \& Sidiropoulos, M. (2010). Another look at the determinants of foreign direct investment in MENA countries: An empirical investigation. Journal of Economic Development, 35(2), 75-95.

World Bank. World development indicators. Retrieved from http:www.worldbank.org

\section{Copyrights}

Copyright for this article is retained by the author(s), with first publication rights granted to the journal.

This is an open-access article distributed under the terms and conditions of the Creative Commons Attribution license (http://creativecommons.org/licenses/by/3.0/). 